\title{
Tea polyphenols alleviate hydrogen peroxide-induced oxidative stress damage through the Mst/Nrf2 axis and the Keap1/Nrf2/HO-1 pathway in murine RAW264.7 cells
}

\author{
QIAN LI $^{1 *}$, ZHAOYAN QIU $^{2 *}$, YAN WANG $^{3 *}$, CHUNYAN GUO $^{4}, \mathrm{XU} \mathrm{CAI}^{1}$, \\ YANDONG ZHANG ${ }^{1}$, LI LIU ${ }^{3}$, HONGKUN XUE $^{1}$ and JINTIAN TANG ${ }^{1}$ \\ ${ }^{1}$ Key Laboratory of Particle and Radiation Imaging, Ministry of Education, Department of Engineering Physics, \\ Tsinghua University, Beijing 100084; ${ }^{2}$ Department of General Surgery, The First Medical Center, \\ Chinese PLA General Hospital, Beijing 100853; ${ }^{3}$ State Key Laboratory of New Drug and Pharmaceutical Process, \\ Shanghai Institute of Pharmaceutical Industry, Shanghai 200437; ${ }^{4}$ Department of Pharmacy, \\ Hebei North University, Zhangjiakou, Hebei 075000, P.R. China
}

Received May 19, 2021; Accepted October 5, 2021

DOI: $10.3892 /$ etm.2021.10908

\begin{abstract}
Tea polyphenols (TPs) are the major bioactive extract from green tea that have been extensively reported to prevent and treat oxidative stress damage. In previous studies, TPs have been demonstrated to protect cells against oxidative injury induced by hydrogen peroxide $\left(\mathrm{H}_{2} \mathrm{O}_{2}\right)$. However, the underlying mechanism remains unclear. The aim of the current study was to investigate whether the protective and regulatory effects of TPs on oxidative stress damage were dependent on the mammalian STE20-like protein kinase (Mst)/nuclear factor (erythroid-derived 2)-like 2 (Nrf2) axis and the Kelch-like ECH-associated protein 1 (Keap1)/Nrf2/ heme oxygenase 1 (HO-1) pathway in RAW264.7 cells, a murine macrophage cell line. Maintaining a certain range of intracellular reactive oxygen species (ROS) levels is critical to basic cellular activities, while excessive ROS generation can override the antioxidant capacity of the cell and result in oxidative stress damage. The inhibition of ROS generation offers an effective target for preventing oxidative damage. The results of the present study revealed that pretreatment with TPs inhibited the production of intracellular ROS and protected
\end{abstract}

Correspondence to: Professor Jintian Tang or Dr Hongkun Xue, Key Laboratory of Particle and Radiation Imaging, Ministry of Education, Department of Engineering Physics, Tsinghua University, 30 Shuangqing Road, Haidian, Beijing 100084, P.R. China

E-mail: tangjt@mail.tsinghua.edu.cn

E-mail: xuehk0906@163.com

*Contributed equally

Key words: tea polyphenols, oxidative stress damage, hydrogen peroxide, reactive oxygen species, mammalian STE20-like protein kinase/nuclear factor (erythroid-derived 2)-like 2 axis, Kelch-like ECH-associated protein 1/nuclear factor (erythroid-derived 2)-like 2/heme oxygenase 1 axis
RAW264.7 cells from $\mathrm{H}_{2} \mathrm{O}_{2}$-induced oxidative damage. TPs was also demonstrated to attenuate the production of nitric oxide and malondialdehyde and increase the levels of antioxidant enzymes (superoxide dismutase, catalase and glutathione peroxidase). In addition, following TPs treatment, alterations in Mst1/2 at the mRNA and protein level inhibited the production of ROS and promoted the self-regulation of antioxidation. TPs-induced Keap1 gene downregulation also increased the expression of Nrf2 and HO-1. Collectively, the results of the present study demonstrated that TPs provided protection against $\mathrm{H}_{2} \mathrm{O}_{2}$-induced oxidative injury in RAW264.7 cells.

\section{Introduction}

Tea polyphenols (TPs) are a group of polyphenol compounds that are mainly extracted from green tea, which contain four substances namely (-)-epigallocatechin-3-gallate (EGCG), (-)-epigallocatechin (EGC), (-)-epicatechin-3-gallate (ECG) and (-)-epicatechin (EC) (1). Polyphenols have been reported to exert bioactive effects that are antioxidant, anti-obesity, anti-inflammatory, cancer preventative, anti-tumor and regulatory of lipid metabolism (2). As one of the best-studied antioxidants, it has been demonstrated that TPs exerts definitive protective effects against oxidative stress, which is associated with various clinical symptoms and diseases, including age-related, neurological, cardiovascular and cerebrovascular diseases, occurring through the elimination of free radicals and the subsequent regulation of anti-oxidases activity $(3,4)$. With a basic structure of $\alpha$-phenyl-benzopyran, the molecular structure of TPs and polyphenolic compounds, particularly the position and number of hydroxyl groups, serve an important role in antioxidant activity (5). Studies have reported that in laboratory experiments and clinical studies, TPs can provide a more robust protective effect against oxidative damage than polyphenolic compounds individually $(6,7)$.

Reactive oxygen species (ROS) are byproducts of normal cellular metabolism. ROS levels are associated with basic cellular activities and cause oxidative stress when ROS 
generation exceeds the antioxidant capacity of the cell (8). Physiologically, a system of oxidant and antioxidant enzymes delicately balance intracellular ROS levels for cellular homeostasis $(9,10)$. The overproduction of ROS can break cell defenses, leading to oxidative stress that induces irreversible damage to the mitochondria, destroying cellular structure and function and causing increased risk for cardiovascular disease, diabetes mellitus, cancer and other diseases (10). Previous studies have shown that TPs exhibit antioxidant effects in the following processes $(11,12)$ : Elimination of free radicals via relatively stable phenolic oxygen radicals formed with ROS; inhibition and inactivity of oxidant enzymes and increased production of antioxidant enzymes. A number of epidemiological studies have revealed that the Kelch-like ECH-associated protein-1 (Keap1)/nuclear factor (erythroid-derived 2)-like 2 (Nrf2) signaling pathway serves an important role in antioxidant function and reduces oxidative stress $(12,13)$. TPs and certain polyphenolic compounds, such as EGCG, stimulate the activity of the heme oxygenase 1 (HO-1) gene by activating the Nrf2/antioxidant response element pathway $(13,14)$.

$\mathrm{H}_{2} \mathrm{O}_{2}$-induced oxidative damage is one of the most widely used cellular models of oxidative stress as the antioxidant effect of potent antioxidants can be evaluated (15). Macrophages are reportedly vulnerable to ROS and their functions are affected by oxidative stress in a direct and indirect manner (16). Macrophages directly kill pathogens through phagocytosis, secreting large quantities of certain bioactive molecules, including ROS and nitric oxide (NO). ROS production is a major defense mechanism against pathogenic infiltration $(17,18)$. However, the sensitivity of macrophages to ROS can lead to cell injury and even cell death (19). $\mathrm{H}_{2} \mathrm{O}_{2}$-induced oxidative damage in macrophages can provide a drug screening platform for identifying potential antioxidants from natural products (20).

A study by Wang et al (21) reveals that the cellular self-protective mechanism of macrophages against oxidative stress involves the mammalian STE20-like protein kinase (Mst)/Nrf2 axis. In the same study, Mst1 and Mst2 maintain cellular redox balance by acting as an ROS sensor and modulating the stability of the antioxidant transcription factor Nrf2. However, the role of the Mst/Nrf2 axis in the protective cellular mechanism against antioxidant damage exerted by TPs remains to be elucidated.

Although a growing number of epidemiological studies $(11,12,22)$ have identified the molecular mechanisms associated with the antioxidant effects exerted by TP, there are a lack of studies assessing the antioxidant effect of TPs in $\mathrm{H}_{2} \mathrm{O}_{2}$-induced oxidative damaged macrophages. The aim of the current study was to evaluate the antioxidant properties and underlying mechanisms of TPs in $\mathrm{H}_{2} \mathrm{O}_{2}$-induced oxidative macrophage injury using RAW264.7 cells.

\section{Materials and methods}

Cell culture. Murine macrophage RAW264.7 cells were purchased from the Cell Bank of the Chinese Academy of Sciences and cultured in DMEM (Biological Industries; Sartorius AG) containing 10\% fetal bovine serum (FBS; Biological Industries; Sartorius AG), $100 \mathrm{U} / \mathrm{ml}$ of penicillin and $100 \mu \mathrm{g} / \mathrm{ml}$ of streptomycin (HyClone; Cytiva), in a humidified atmosphere containing $5 \% \mathrm{CO}_{2}$ at $37^{\circ} \mathrm{C}$. For all experiments, cells were incubated with various concentrations $(0.1,0.5$ and $1.0 \mu \mathrm{g} / \mathrm{ml}$ ) of TPs (purity $\geq 98.0 \%$; cat. no. CAS84650-60-2; Beijing Solarbio Science \& Technology Co., Ltd.; containing 46.8\% EGCG, $17.3 \%$ EGC, $5.2 \%$ EC and $1.5 \%$ ECG; Fig. S1) for $12 \mathrm{~h}$ prior to the addition of $\mathrm{H}_{2} \mathrm{O}_{2}$ for $12 \mathrm{~h}$. EGCG, EGC, ECG and EC were bought from Aladdin. Methanol of HPLC-grade was purchased from Sigma-Aldrich (Merck KGaA).

HPLC analysis. The appropriate amounts of four standard substances (EGCG, EGC, EC and ECG), were accurately weighed and dissolved in $20 \%$ methanol (v/v). The tea polyphenol samples were prepared with $20 \%$ methanol and injected into the HPLC system for analysis after filtering through $0.22 \mu \mathrm{m}$ syringe filters.

The analysis was carried out using an LC 15 (Shimadzu Corporation) for the chromatographic determination. The sample was injected into a C18 analytical column $(4.6 \mathrm{~mm}$ I.D x $150 \mathrm{~mm}, 3.0 \mu \mathrm{m}$ particle size; Waters Corporation). The mobile phase was $0.1 \%$ formic acid solution (solvent $\mathrm{A}$ ) and methanol (solvent B). The Diode-Array Detection acquisition wavelength was set at $275 \mathrm{~nm}$. The gradient elution programmer was as follows: $\sim 0-2 \mathrm{~min}, 2 \% \mathrm{~B} ; \sim 2-13 \mathrm{~min}$, $2-90 \% \mathrm{~B} ; \sim 13-16 \mathrm{~min}, 100 \%$. The flow rate was of $0.3 \mathrm{ml} / \mathrm{min}$, and the column temperature was set at $40^{\circ} \mathrm{C}$. The injection volume was $5 \mu \mathrm{l}$.

$\mathrm{H}_{2} \mathrm{O}_{2}$-induced oxidative stress model. RAW264.7 cells were inoculated into 96-well plates at a density of $4 \times 10^{3}$ cells/well at $37^{\circ} \mathrm{C}$ in a humidified $5 \% \mathrm{CO} 2$ incubator for $12 \mathrm{~h}$. Cells were treated with different final concentrations of $\mathrm{H}_{2} \mathrm{O}_{2}(0,50$, $100,200,300,400,500,600,700$ and $800 \mu \mathrm{M}$ ) diluted with complete medium for $0,4,8,12$ and $24 \mathrm{~h}$. Cells were subsequently treated with Cell Counting Kit-8 (CCK-8; Shanghai Yeasen Biotech Co., Ltd.) for $3 \mathrm{~h}$. Absorbance was detected at a wavelength of $450 \mathrm{~nm}$ and the results were expressed as a percentage.

Cell viability assay. TPs cytotoxicity in RAW264.7 cells was analyzed using a CCK-8 assay in accordance with the manufacturer's protocol. RAW264.7 cells were seeded into 96-well plates at a density of $4 \times 10^{3}$ cells/well and left to adhere. Cells were then treated with 0.0, 0.1, 0.5, 1.0, 5.0 and $10.0 \mu \mathrm{g} / \mathrm{ml}$ TPs for $24 \mathrm{~h}$. Subsequently, $10 \mu \mathrm{l} \mathrm{CCK}-8$ reagent was added to each well and incubated at $37^{\circ} \mathrm{C}$ for $3 \mathrm{~h}$. The absorbance value at a wavelength of $450 \mathrm{~nm}$ was measured using the Varioskan Flash microplate reader (Thermo Fisher Scientific, Inc.). Each evaluation of each concentration was repeated three times.

Effect of TPs on the proliferation of $\mathrm{H}_{2} \mathrm{O}_{2}$-injured cells. Cells were seeded into 96 -well plates at a density of $4 \times 10^{3}$ cells/well and pre-incubated at $37^{\circ} \mathrm{C}$ for $24 \mathrm{~h}$. The culture medium supernatant was replaced with an equal volume of solution containing different concentrations of TPs $(0.1,0.5$ and $1.0 \mu \mathrm{g} / \mathrm{ml}$ ) and incubated at $37^{\circ} \mathrm{C}$ for $12 \mathrm{~h}$. Subsequently, samples were treated with $400 \mu \mathrm{M} \mathrm{H}_{2} \mathrm{O}_{2}$ at $37^{\circ} \mathrm{C}$ for a further $12 \mathrm{~h}$. Proliferations was evaluated using the aforementioned CCK-8 method. 
A<smiles>[R]c1cc([C@H]2Oc3cc(O)cc(O)c3CC2[R2])cc(O)c1O</smiles>

$$
\begin{array}{llll}
1 & \mathrm{EC} & \mathrm{R}_{1}=\mathrm{H} & \mathrm{R}_{2}=\mathrm{OH} \\
2 \mathrm{EGC} & \mathrm{R}_{1}=\mathrm{OH} & \mathrm{R}_{2}=\mathrm{OH} \\
3 \text { ECG } & \mathrm{R}_{1}=\mathrm{H} & \mathrm{R}_{2}=\mathrm{C}_{7} \mathrm{H}_{5} \mathrm{O}_{5} \\
4 \text { EGCG } & \mathrm{R}_{1}=\mathrm{OH} & \mathrm{R}_{2}=\mathrm{C}_{7} \mathrm{H}_{5} \mathrm{O}_{5}
\end{array}
$$

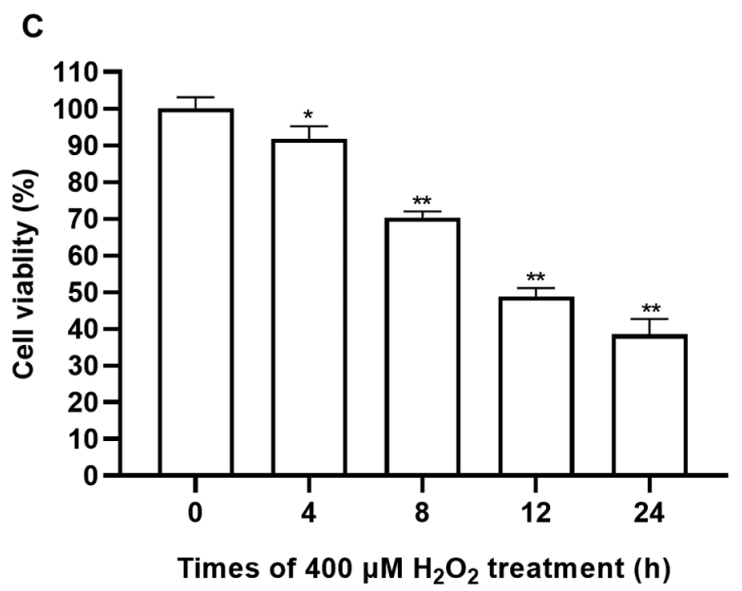

B

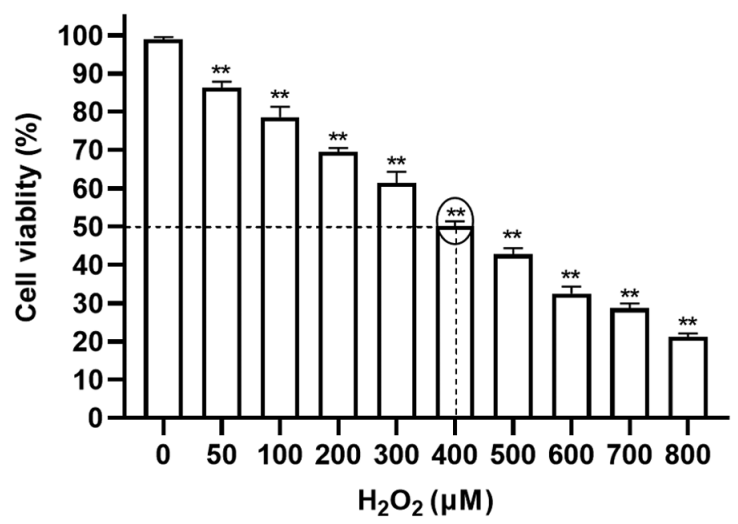

D

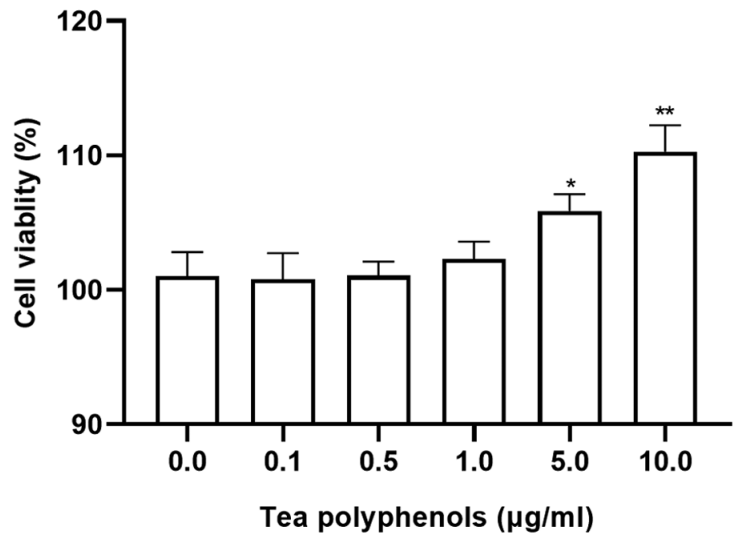

Figure 1. Effect of $\mathrm{H}_{2} \mathrm{O}_{2}$ and TPs on cell viability of RAW264.7 cells by CCK-8. (A) Chemical structures of major catechins in TPs. (B) RAW264.7 cells were treated with various concentrations of $\mathrm{H}_{2} \mathrm{O}_{2}(0-800 \mu \mathrm{M})$ for $12 \mathrm{~h}$ and (C) with $400 \mu \mathrm{M} \mathrm{H}_{2} \mathrm{O}_{2}$ in different times and cell viability was analyzed by CCK-8 assay. (D) RAW264.7 cells treated with TPs $(0.1,0.5,1.0,5.0$ and $10.0 \mu \mathrm{g} / \mathrm{ml})$ for $24 \mathrm{~h}$. Data are the means \pm SD from three independent experiments. ${ }^{*} \mathrm{P}<0.05$, ${ }^{* *} \mathrm{P}<0.01$ vs. the control group. TPs, tea polyphenols.

ROS assay. ROS production was estimated using an ROS Assay kit (Beyotime Institute of Biotechnology) as previously described (23). RAW264.7 cells $\left(2 \times 10^{5}\right.$ cells $\left./ \mathrm{ml}\right)$ were cultured in a 24 -well plates and incubated at $37^{\circ} \mathrm{C}$ overnight. Cells were pretreated with different concentrations $(0.1,0.5$ and $1.0 \mu \mathrm{g} / \mathrm{ml}$ ) of TPs at $37^{\circ} \mathrm{C}$ for $12 \mathrm{~h}$, after which each well plate was exposed to $400 \mu \mathrm{M} \mathrm{H}_{2} \mathrm{O}_{2}$ at $37^{\circ} \mathrm{C}$ for a further $12 \mathrm{~h}$. Subsequently, the cells were washed three times with cold PBS and incubated with $5 \mu \mathrm{M} \mathrm{DCFH}_{2}$-DA (Gibco; Thermo Fisher Scientific, Inc.) at $37^{\circ} \mathrm{C}$ for $30 \mathrm{~min}$. RAW264.7 cells were washed with DMEM culture medium and determined the fluorescent intensity was determined using a Bio-Rad ZE5 cell analyzer (Bio-Rad Laboratories, Inc.).

Antioxidant enzyme activity assays. RAW264.7 cells were seeded into 6-well plates with a density of $5 \times 10^{5}$ cells/cell and cultured at $37^{\circ} \mathrm{C}$ overnight. Cells were treated with $0.1,0.5$ and $1.0 \mu \mathrm{g} / \mathrm{ml}$ of TPs at $37^{\circ} \mathrm{C}$ for $12 \mathrm{~h}$, followed by $400 \mu \mathrm{M} \mathrm{H}_{2} \mathrm{O}_{2}$ treatment at $37^{\circ} \mathrm{C}$ for an additional $12 \mathrm{~h}$. At the end of incubation, cells were collected for the detection of NO contents and superoxide dismutase (SOD), catalase (CAT), malondialdehyde (MDA) and glutathione peroxidase (GSH-Px) activity using Griess Regent and test kits (Nanjing Jiancheng Bioengineering Institute), respectively.
Reverse transcription-quantitative ( $R T-q) P C R$. Total RNA was extracted from $5 \times 10^{6}$ RAW264.7 cells using TRIzol ${ }^{\circledR}$ reagent according to its instructions (Invitrogen; Thermo Fisher Scientific, Inc.) and quantified at $260 \mathrm{~nm}$ using a NanoPhotometer (cat. no. P300; Implen GmbH). cDNA was synthesized from $1 \mu \mathrm{g}$ total RNA obtained from each sample using the MonScript RTIII all-in-one Mix according to the manufacturer's protocols (Monad Biotech Co., Ltd.). Subsequently, RT-qPCR was performed to quantify mRNA expression levels using the SYBR Green qPCR Mix (Monad Biotech Co., Ltd.) with the AriaMx RT-PCR system (Agilent Technologies, Inc.). The primer sequences used for PCR were as follows: HO-1 forward, 5'-GAAATCATCCCTTGCACGCC-3' and reverse, 5'-CCTGAGAGGTCACCCAGGTA-3'; Keap1 forward, 5'-TGGGTCAAATACGACTGCCC-3' and reverse, 5'-ATCATCCGCCACTCATTCCT-3'; Nrf2 forward, 5'-ACATGGAGCAAGTTTGGCAG-3' and reverse, 5'-TGGAGAGGATGCTGCTGAAA-3'; Mst1 forward, 5'-CAGCCTGCACTCAGACCAAC-3' and reverse, 5'- TGGCAGTGGAAGAAGCTATGTC-3'; Mst2 forward, 5'-CCAGGCCCTATGTCCAACAG-3' and reverse, 5'-TGCCTCCTCTTCTTCGCATC-3'; $\beta$-actin forward, 5'-AGTGTGACGTTGACATCCGT-3' and reverse, 5'-AGCTCAGTAACAGTCCGCCTA-3'. The amplification 
A

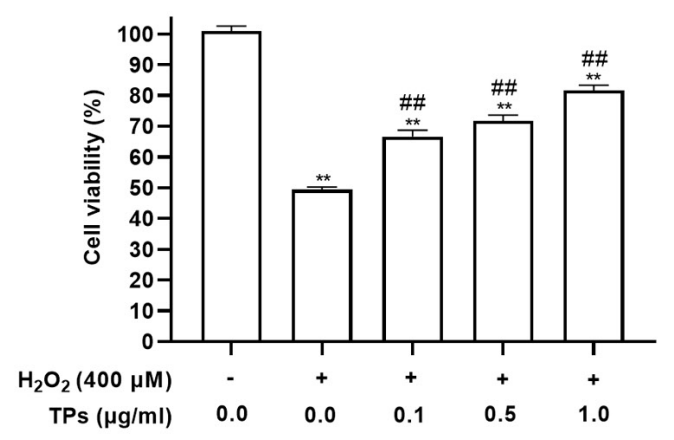

B

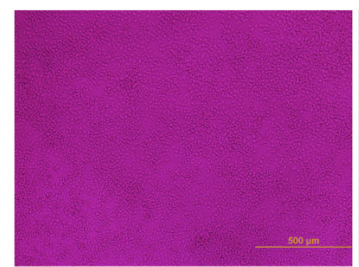

$\mathrm{H}_{2} \mathrm{O}_{2}+0.1 \mu \mathrm{g} / \mathrm{ml}$ TPs

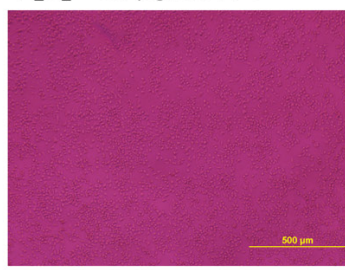

$\mathrm{H}_{2} \mathrm{O}_{2}$

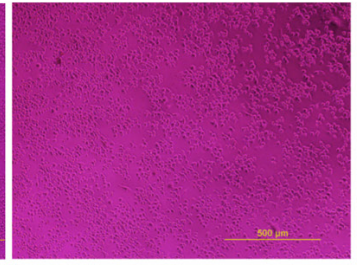

$\mathrm{H}_{2} \mathrm{O}_{2}+0.5 \mu \mathrm{g} / \mathrm{ml} \mathrm{TPs}$

$\mathrm{H}_{2} \mathrm{O}_{2}+1.0 \mu \mathrm{g} / \mathrm{ml} \mathrm{TPs}$

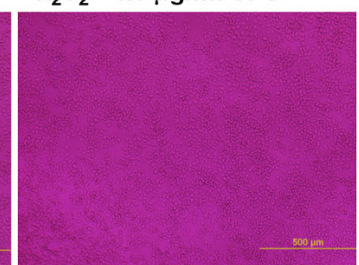

Figure 2. Protective effects of TPs on $\mathrm{H}_{2} \mathrm{O}_{2}$-induced RAW264.7 cells injury. (A) Cell viability and (B) representative images (scale bars $=500 \mu$ m; Magnification, x10) of $\mathrm{H}_{2} \mathrm{O}_{2}$-induced RAW264.7 cells pretreated with different concentrations of TPs $(0.1,0.5 \mathrm{and} 1.0 \mu \mathrm{g} / \mathrm{ml})$ for $12 \mathrm{~h}$. The results are expressed as the means $\pm \mathrm{SD}$ of three independent experiments. ${ }^{* *} \mathrm{P}<0.01$ vs. Control, ${ }^{\# \#} \mathrm{P}<0.01$ vs. the $\mathrm{H}_{2} \mathrm{O}_{2}$ group. TPs, tea polyphenols.

A

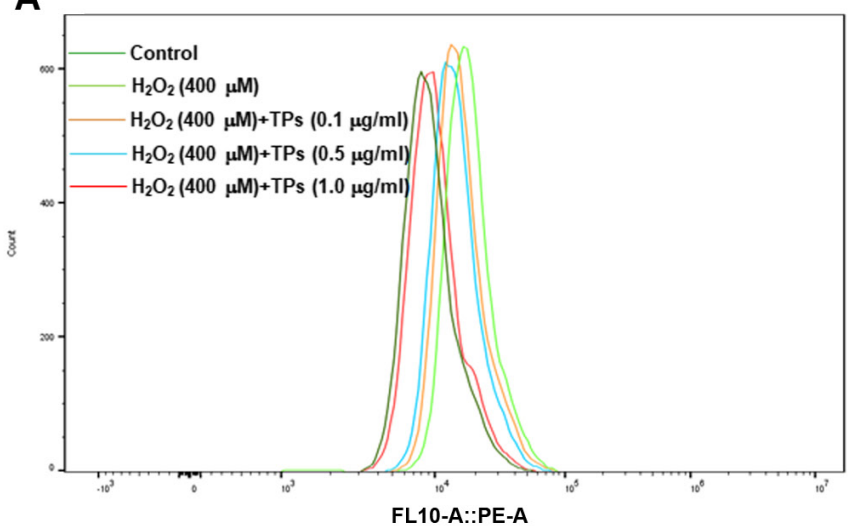

B

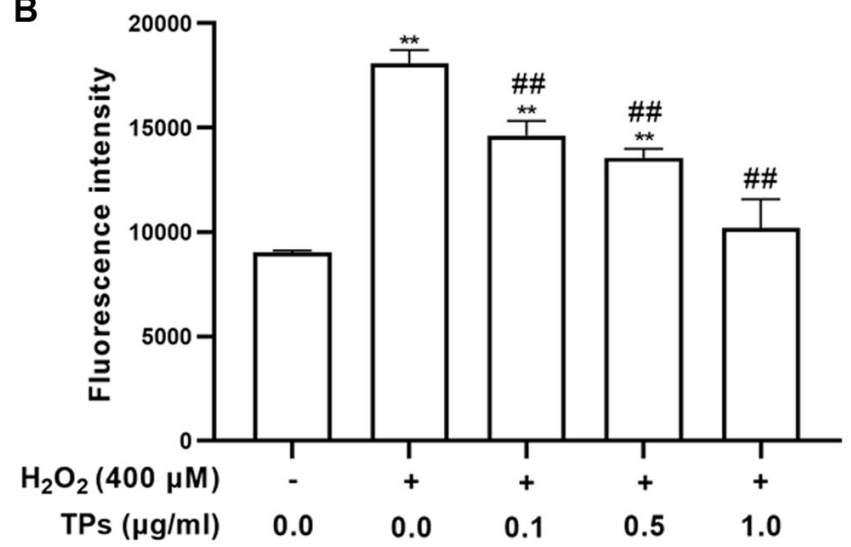

Figure 3. TPs inhibited intracellular ROS generations of RAW264.7 cells under oxidative stress. (A) Flow cytometry of RAW264.7 cells stained for 30 min with ROS dye DCFH2-DA. RAW264.7 cells were incubated with or not for TPs $(0.1,0.5$ and $1.0 \mu \mathrm{g} / \mathrm{ml})$ for $12 \mathrm{~h}$ followed by $400 \mu \mathrm{M} \mathrm{H} \mathrm{O}_{2}$ for another $12 \mathrm{~h}$. (B) Statistical analysis of the ROS per group. ${ }^{* *} \mathrm{P}<0.01$ vs. the control group, ${ }^{\# \#} \mathrm{P}<0.01$ vs. the $\mathrm{H}_{2} \mathrm{O}_{2}$ group. TPs, tea polyphenols.

program included an initial denaturation step at $95^{\circ} \mathrm{C}$ for $30 \mathrm{sec}$, followed by 40 cycles of denaturation at $94^{\circ} \mathrm{C}$ for $5 \mathrm{sec}$, annealing at $58^{\circ} \mathrm{C}$ for $30 \mathrm{sec}$ and extension at $70^{\circ} \mathrm{C}$ for $5 \mathrm{sec}$. The experiments were repeated in triplicate using independent samples. Relative gene expression was analyzed using the $2^{-\Delta \Delta \mathrm{Cq}}$ method with $\beta$-actin as an internal control (24).

Western blot analysis. Cells were lysed using RIPA lysis buffer (Beyotime Institute of Biotechnology) containing 1\% phenylmethylsulfonyl fluoride, protease inhibitors and phosphatase inhibitors. The concentration of protein was subsequently quantified using a BCA protein estimation kit (Beyotime Institute of Biotechnology). A total of $40 \mu \mathrm{g}$ protein was loaded onto $12 \%$ SDS-PAGE gels and transferred onto a nitrocellulose membrane (EDM Millipore). The membrane was then blocked with 5\% nonfat milk in PBST (PBS containing 0.05\% Tween-20) at room temperature for $2 \mathrm{~h}$ and incubated with the following primary antibodies for $14 \mathrm{~h}$ at $4^{\circ} \mathrm{C}$ : Keap1 (cat. no. sc-515432; 1:500; Santa Cruz Biotechnology, Inc.), Mst1 (cat. no. ab51134; 1:1,000; Abcam), Mst2 (cat. no. ab70546; 1:1,000; Abcam), Nrf2 (cat. no. ab92946; 1:1,000; Abcam), HO-1 (cat. no. ab52947;
1:1,000; Abcam) and $\beta$-actin (cat. no. ab8226; 1:1,000, Abcam). After washing three times with PBST, the membrane was incubated for $1 \mathrm{~h}$ with HRP-conjugated IgG (cat. nos. ab6721 and ab6728; 1:10,000; Abcam) at room temperature. The resultant signals were detected using the LumigenTMA- 6 kit (Cytiva). The relative protein levels were normalized to $\beta$-actin, which was used as the internal control. Quantity One software (Bio-Rad Laboratories, Inc.) was used for densitometry.

Statistical analysis. All data were presented as the mean \pm SD of three independent experiments and analyzed using GraphPad Prism 8.0.1 software (GraphPad Software, Inc.). Multiple comparisons were analyzed via one-way ANOVA followed by Tukey's comparison post hoc test. $\mathrm{P}<0.05$ was considered to indicate a statistically significant difference.

\section{Results}

Effects of $\mathrm{H}_{2} \mathrm{O}_{2}$ and TPs on RAW264.7 cells. To investigate the cytotoxicity of TPs and $\mathrm{H}_{2} \mathrm{O}_{2}$ in RAW264.7 cells, the viability of RAW264.7 cells was evaluated following treatment with 

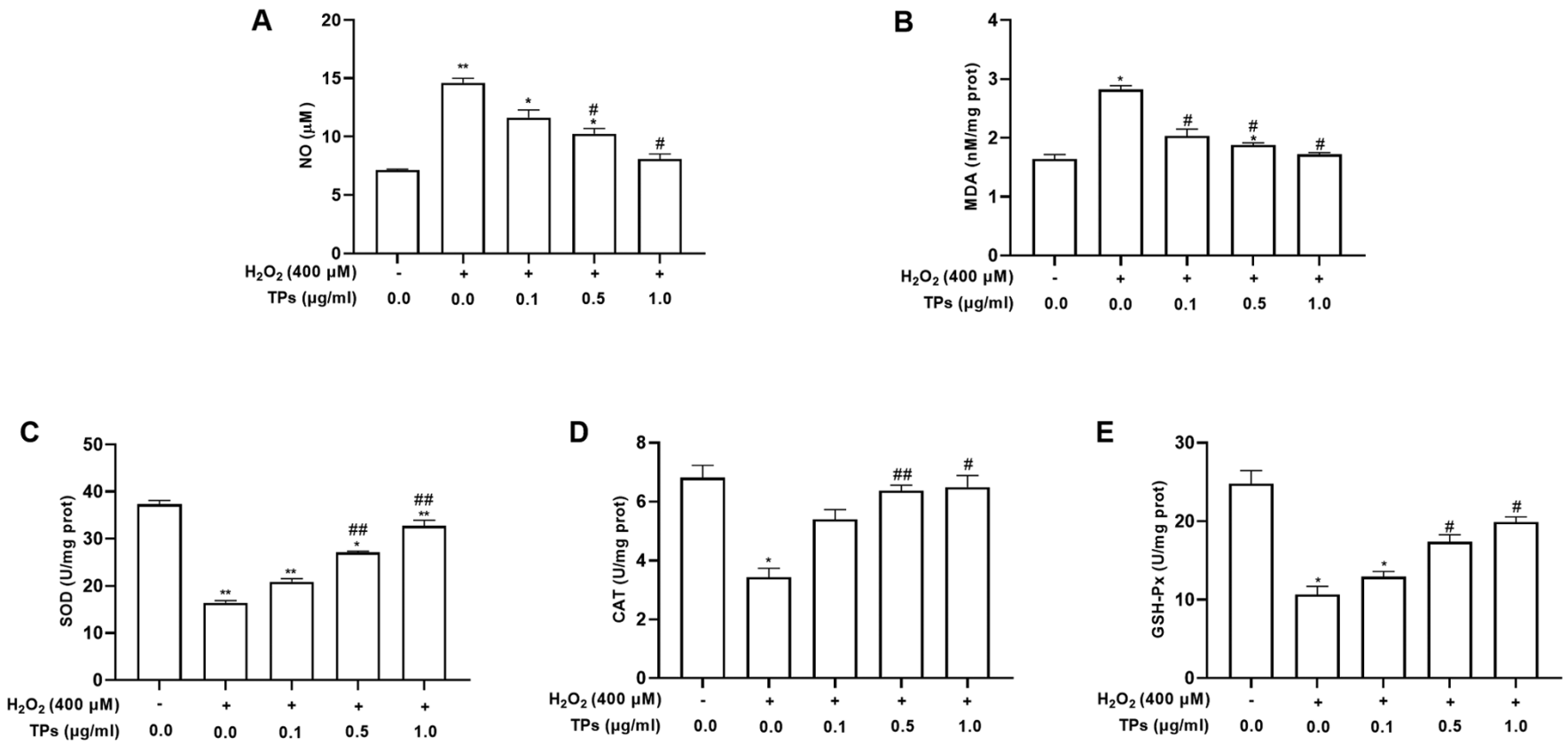

Figure 4. Evaluation of NO level and activities of the antioxidant enzymes. The effects of TPs on the cellular concentrations of (A) NO and (B) MDA. The effects of TPs on the activities of (C) SOD, (D) CAT and (E) GSH-Px. The results are expressed as the mean \pm SD of three independent experiments. "P<0.05 and ${ }^{* *} \mathrm{P}<0.01$ vs. the control group, ${ }^{\#} \mathrm{P}<0.05$ and ${ }^{\# \#} \mathrm{P}<0.01$ vs. the $\mathrm{H}_{2} \mathrm{O}_{2}$ group. $\mathrm{NO}$, nitric oxide; TPs, tea polyphenols; $\mathrm{SOD}$, superoxide dismutase; CAT, catalase; GSH-Px, glutathione peroxidase.

various concentrations of TPs or $\mathrm{H}_{2} \mathrm{O}_{2}$. The chemical structures of major catechins in TPs were shown in Fig. 1A. As presented in Fig. 1B, the viability of cells exposed to $\mathrm{H}_{2} \mathrm{O}_{2}$ decreased in a dose-dependent manner within $12 \mathrm{~h}$. Additionally, treatment with $400 \mu \mathrm{M} \mathrm{H}_{2} \mathrm{O}_{2}$ exhibited 50\% inhibition within $12 \mathrm{~h}$ (Fig. 1B and C) and as such was selected for use in subsequent experiments. In present study, CCK-8 assays showed that TPs did not have significant effect on cellular viability after $24 \mathrm{~h}$ treatment with $0.1,0.5$ and $1.0 \mu \mathrm{g} / \mathrm{ml}$ (Fig. 1D). Therefore, TPs of $0.1,0.5$ and $1.0 \mu \mathrm{g} / \mathrm{ml}$ were adopted as the suitable concentrations for the subsequent experiments.

TPS attenuate $\mathrm{H}_{2} \mathrm{O}_{2}$-induced cell injury in an oxidative stress model. $\mathrm{H}_{2} \mathrm{O}_{2}$ can induce mitochondrial injury and membrane structure disruption due to its excessive generation (25). CCK-8 analysis was performed to evaluate the protective effects of TPs on the viability of cells exposed to $\mathrm{H}_{2} \mathrm{O}_{2}$-induced cytotoxicity. As presented in Fig. 2, TPs reduced $\mathrm{H}_{2} \mathrm{O}_{2}$-induced cytotoxic effects. Additionally, pretreatment with TPs at $0.1,0.5$ and $1.0 \mu \mathrm{g} / \mathrm{ml}$ for $24 \mathrm{~h}$, followed by exposure to $400 \mu \mathrm{M} \mathrm{H}_{2} \mathrm{O}_{2}$ markedly increased cell viability in a TPs dose-dependent manner (Fig. 2A). Morphological observations revealed that the number of RAW264.7 cells in the $\mathrm{H}_{2} \mathrm{O}_{2}$ group was decreased, while pretreatment with TPs could prevent this effect (Fig. 2B). The results indicated that TPs could protect cells against $\mathrm{H}_{2} \mathrm{O}_{2}$-induced injury.

TPs inhibit ROS production in an oxidative stress model. Given the essential requirement for cellular homeostasis, ROS are generated in various metabolic processes; however, external $\mathrm{H}_{2} \mathrm{O}_{2}$ can lead to the excessive production of ROS, which causes damage to cell lipids, proteins and organelles (26). The current study measured intracellular ROS content via flow cytometry using DCFH2-DA. As presented in Fig. 3A and B, following cell exposure to $\mathrm{H}_{2} \mathrm{O}_{2}$ for $12 \mathrm{~h}$, ROS levels were significantly increased in the $\mathrm{H}_{2} \mathrm{O}_{2}$ treated group compared with the control group $(\mathrm{P}<0.05)$. However, ROS levels were significantly decreased in the three TPs treated groups compared with the $\mathrm{H}_{2} \mathrm{O}_{2}$ group $(\mathrm{P}<0.05)$. The results indicated that TPs enhanced RAW264.7 cell ROS elimination in a dose-dependent.

TPs alter the $\mathrm{H}_{2} \mathrm{O}_{2}$-induced expression of antioxidant enzyme activity in RAW264.7 cells. According to previous studies, TPs, or the main contents, can reduce levels of NO and MDA, simultaneously increasing the production of SOD, GSH-Px and CAT $(27,28)$. To determine the antioxidant effect of TPs under oxidative stress, the activities of NO and antioxidant enzymes (SOD, CAT, MDA and GSH-Px) were assessed in TPs-pretreated cells. The results revealed that increased NO and MDA levels induced by $\mathrm{H}_{2} \mathrm{O}_{2}$ were significantly reduced in TPs pretreated groups $(\mathrm{P}<0.05$; Fig. $4 \mathrm{~A}$ and $\mathrm{B})$. In addition, the three groups treated with TPs demonstrated significantly declined NO and MDA activities compared with the oxidative injure group $(\mathrm{P}<0.05)$. As presented in Fig. $4 \mathrm{C}-\mathrm{E}$, the $\mathrm{H}_{2} \mathrm{O}_{2}$ treated group demonstrated significantly decreased activities of SOD, CAT and GSH-Px compared with the control group $(\mathrm{P}<0.05)$. In addition, significant increased activities of SOD, CAT and GSH-Px were detected in all TPs-pretreated groups compared with the $\mathrm{H}_{2} \mathrm{O}_{2}$ group $(\mathrm{P}<0.05)$.

Mst/Nrf2 axis and Keapl/Nrf2/HO-1 pathway-related gene and protein expressions. Recent studies have demonstrated that ROS activates the Mst/Nrf2 axis and Keap1/Nrf2/HO-1 pathway to initiate cellular self-protective mechanisms against oxidative damage $(19,21)$. To clarify the underlying antioxidant 

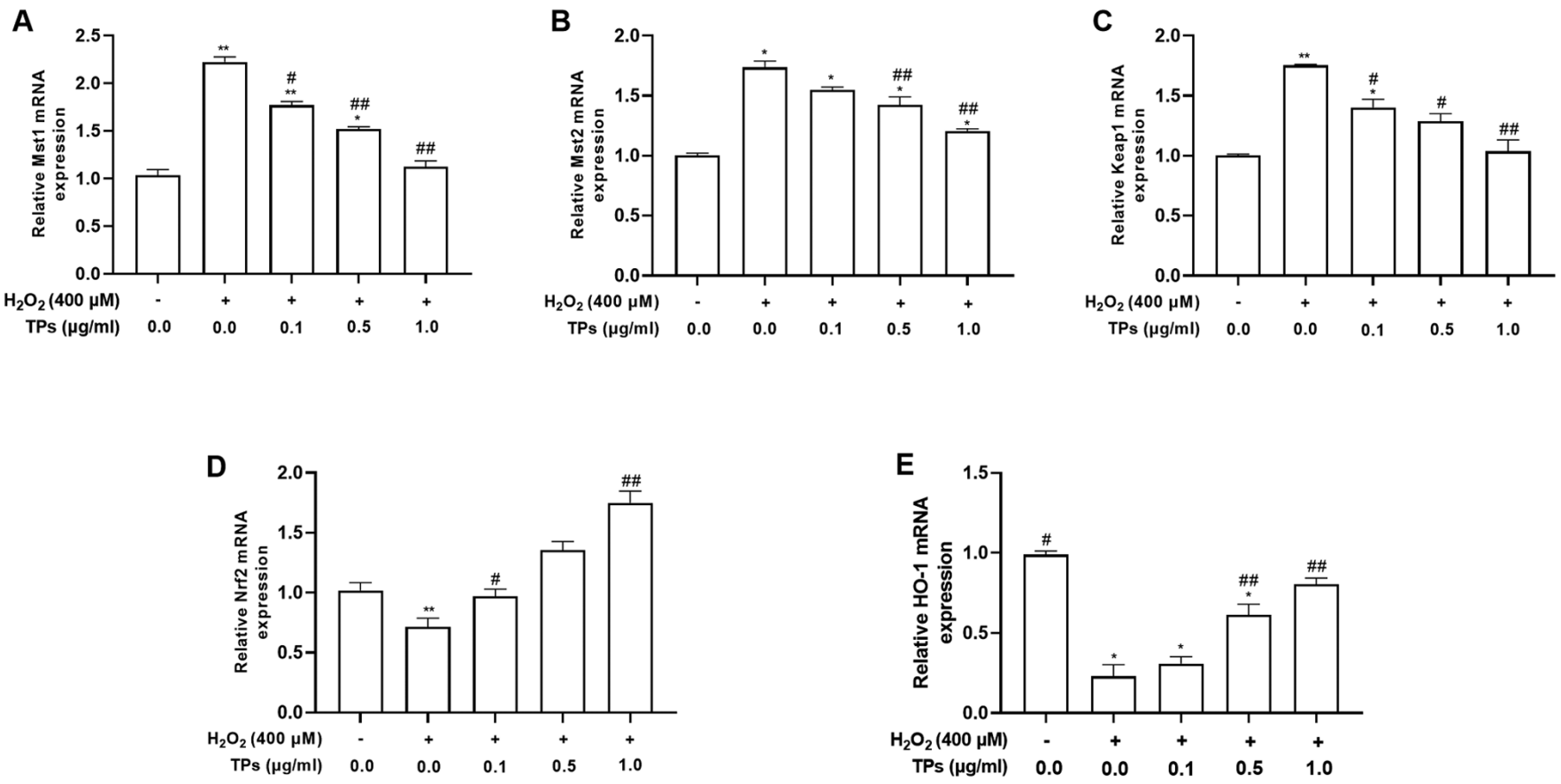

Figure 5. mRNA level changes after RAW264.7 cells were treated with TPs against oxidative damage. The (A) Mst1, (B) Mst2, (C) Keap1, (D) Nrf2 and (E) HO-1 mRNA expression levels were estimated using reverse transcription-quantitative PCR. Each bar represents the mean \pm SD of three independent experiments. ${ }^{*} \mathrm{P}<0.05$ or ${ }^{* *} \mathrm{P}<0.01$ vs. the control group, ${ }^{~} \mathrm{P}<0.05$ or ${ }^{\# \prime} \mathrm{P}<0.01$ vs. the $\mathrm{H}_{2} \mathrm{O}_{2}$ group. TPs, tea polyphenols; Mst, mammalian $\mathrm{STE} 20$-like protein kinase; Keap1, Kelch-like ECH-associated protein 1; Nrf2, nuclear factor (erythroid-derived 2)-like 2; HO-1, heme oxygenase 1.

mechanisms of TP, the mRNA and total protein levels of the Mst/Nrf2 axis and Keap1/Nrf2/HO-1pathway were measured using RT-qPCR and western blotting, respectively.

After $12 \mathrm{~h}$ of $\mathrm{H}_{2} \mathrm{O}_{2}$ and/or $24 \mathrm{~h}$ of TPs pretreatment, the mRNA expression levels of Mst1, Mst2, Keap1, Nrf2 and HO-1 were evaluated (Fig. 5). The results demonstrated that Mst1, Mst2 and Keap1 mRNA levels were significantly increased $(\mathrm{P}<0.05)$, while Nrf2 and HO-1 mRNA levels were significantly decreased $(\mathrm{P}<0.05)$ in the $\mathrm{H}_{2} \mathrm{O}_{2}$ group compared with the control group. TPs treatment reduced the mRNA expression levels of Mst1 and Mst2 in a concentration-dependent manner, but could not fully restore levels to those prior to $\mathrm{H}_{2} \mathrm{O}_{2}$ oxidative stress induction (Fig. 5A and B). In addition, the three TPs groups resulted in decreased Keap1 mRNA expression levels compared with the $\mathrm{H}_{2} \mathrm{O}_{2}$-treated group ( $\mathrm{P}<0.01$; Fig. 5C). TPs-pretreated groups also demonstrated significantly increased $\mathrm{Nrf} 2$ and $\mathrm{HO}-1$ mRNA expression levels compared with the $\mathrm{H}_{2} \mathrm{O}_{2}$ group ( $\mathrm{P}<0.01$; Fig. 5D and E).

In support of the results of RT-qPCR, western blot analysis also revealed that $\mathrm{H}_{2} \mathrm{O}_{2}$ treatment significantly affected the Mst/ Nrf2 axis and Keap1/Nrf2/HO-1 pathway. As presented in Fig. 6, when compared with the control group, $\mathrm{H}_{2} \mathrm{O}_{2}$ treatment resulted in increased expression of Mst1, Mst2 and Keap1 (Fig. 6A-D) and decreased expression of Nrf2 and HO-1 (Fig. 6E and F). These effects were all reversed by preincubation with TP.

\section{Discussion}

Accumulating studies indicate that plant bioactive polyphenols exhibit higher antioxidant activity and lower toxicity than synthetic compounds (29-31). Research in our laboratory (Tsinghua University; Beijing) has focused on the bioactive effects of natural low molecular weight polyphenols, including lychee, tea, blueberry and other polyphenols derived from edible plants (32-34). As recognized natural antioxidants, TPs and their main four substances have been used in the prevention and treatment of clinical diseases involving oxidative damage. The TPs content was $~ 1.8-3.6 \mathrm{mg}$ per gram of dry tea leaves; in addition, $75-147 \mu \mathrm{g} / \mathrm{ml}$ of polyphenols was dissolved in $100 \mathrm{ml}$ tea liquor from $1 \mathrm{~g}$ leaf $(35,36)$. Frei and Higdon (37) reported that one cup of tea ( $2 \mathrm{~g}$ of tea leaves infused in hot water for $\sim 1-3 \mathrm{~min}$ ) will provide $0.15 \sim 0.2 \mathrm{~g}$ of flavonoids. As few as 2-3 cups/day of tea will therefore supply a significant contribution to the total flavonoid intake in most individuals, which is estimated to average $1 \mathrm{~g}$ per day. Note that the concentrations of TPs by drinking tea are much higher than the experimental concentrations.

High doses of polyphenols are reported to exert positive effects as well as some negative effects (12). In the pre-experiments of the present study, the effect of $\sim 0-100 \mu \mathrm{g} / \mathrm{ml}$ TPs on the cell viability of RAW264.7 cells was assessed. The experiment results indicated that the non-cytotoxic concentrations were $\leq 1.0 \mu \mathrm{g} / \mathrm{ml}$ for TPs; $5.0 \mu \mathrm{g} / \mathrm{ml}$ and $10.0 \mu \mathrm{g} / \mathrm{ml}$ enhanced cell viability of RAW264.7 cells; $50.0 \mu \mathrm{g} / \mathrm{ml}$ and $100.0 \mu \mathrm{g} / \mathrm{ml}$ inhibited the viability of RAW264.7 cells. Similar experimental results are reported by Lagha and Grenier (38); $62.5 \mu \mathrm{g} / \mathrm{ml}$ green tea extract induces cell viability, and $\geq 62.5 \mu \mathrm{g} / \mathrm{ml}$ inhibits cell proliferation of U937 macrophage-like cells. This finding differs from the fact that TPs inhibits the growth of tumor cells in a concentration-dependent manner. This phenomenon is puzzling and the underlying mechanisms remain unclear. The regulation of TPs on the cell viability in macrophages will become the focus of future research. Experiments performed on animals have shown that high concentrations of green tea extract $(\sim 500-2000 \mathrm{mg} / \mathrm{kg})$ and of single tea phenolics, such as EGCG $(150 \mathrm{mg} / \mathrm{kg} / \mathrm{day})$ 
A

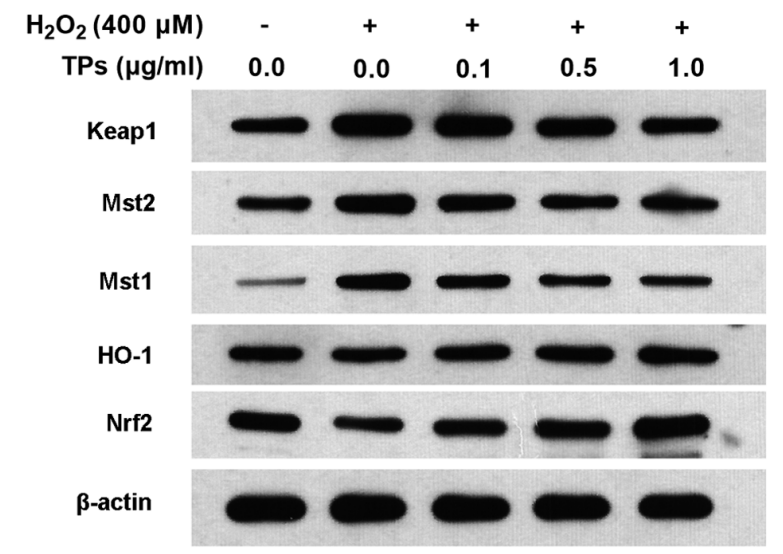

C

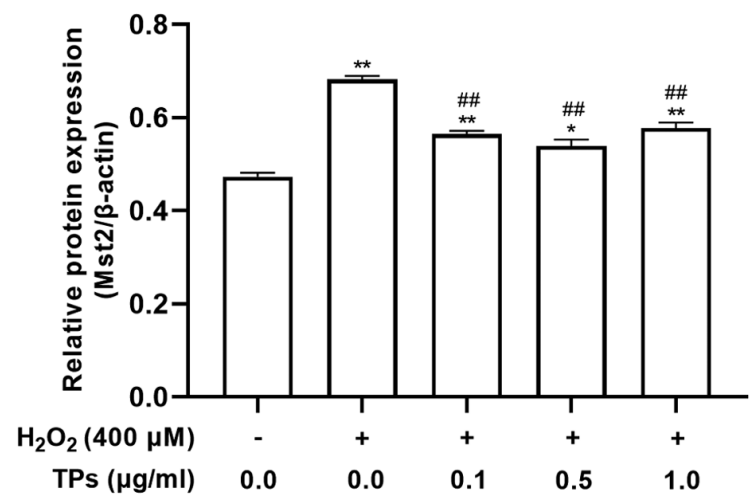

E

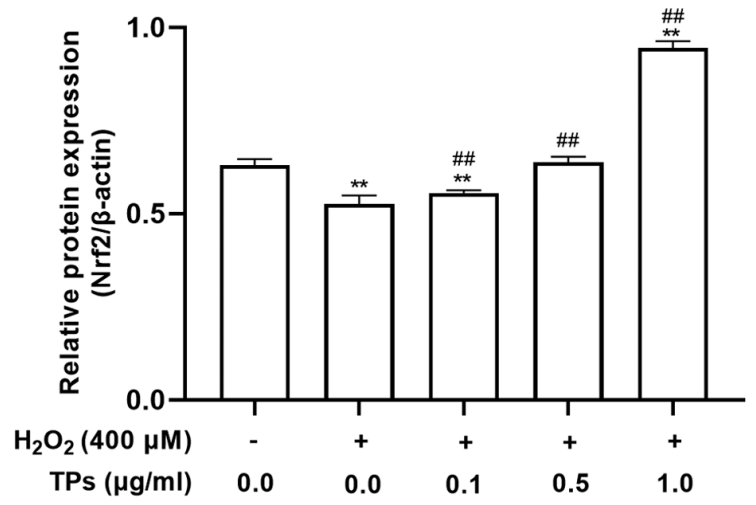

B

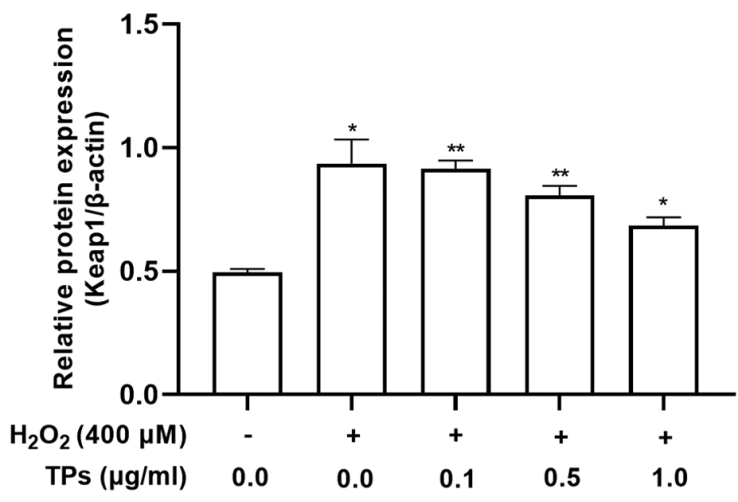

D

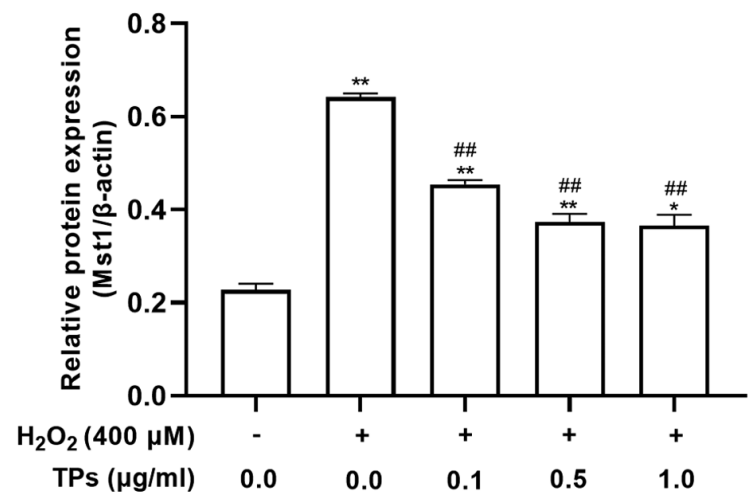

$\mathbf{F}$

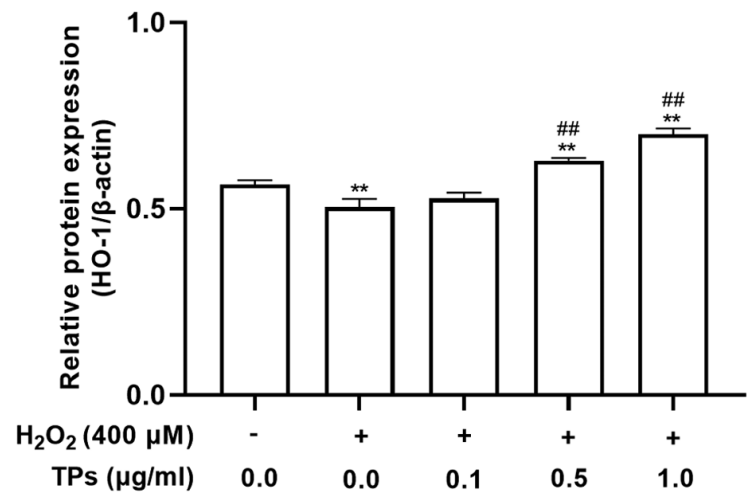

Figure 6. Effects of TPs on the Mst-Nrf2 axis and Keap1/Nrf2/HO-1 pathway protein expression on RAW264.7 cells under oxidative damage. (A) The protein expression levels were tested using western blotting. (B) Keap1, (C) Mst2, (D) Mst1, (E) Nrf2 and (F) HO-1 proteins levels were quantified via densitometry and were normalized to $\beta$-actin. Each bar represents the mean $\pm \mathrm{SD}$ of three independent experiments. ${ }^{*} \mathrm{P}<0.05$ or ${ }^{* *} \mathrm{P}<0.01$ vs. the control group, ${ }^{\# \#} \mathrm{P}<0.01$ vs. the $\mathrm{H}_{2} \mathrm{O}_{2}$ group. TPs, tea polyphenols; Mst, mammalian STE20-like protein kinase; Nrf2, nuclear factor (erythroid-derived 2)-like 2; Keap1, Kelch-like ECH-associated protein 1; HO-1, heme oxygenase 1.

produce toxicity in the liver, intestine and kidneys $(39,40)$ Similarly, a previous study revealed that the continuous administration of high-dose plant bioactive polyphenols does not achieve the expected continuous prophylactic and therapeutic effects in the treatment of RAW264.7 cells and oxidative-damaged
RAW264.7 cells. The data from the present study suggested that low doses of TPs exerted effective preventive biological effects. The doses of TPs $(0.1,0.5,1.0 \mu \mathrm{g} / \mathrm{ml})$ that protected RAW264.7 cells against $\mathrm{H}_{2} \mathrm{O}_{2}$-induced injury were much lower compared with those used in other studies $(\sim 10-100 \mu \mathrm{g} / \mathrm{ml}$ TPs; 


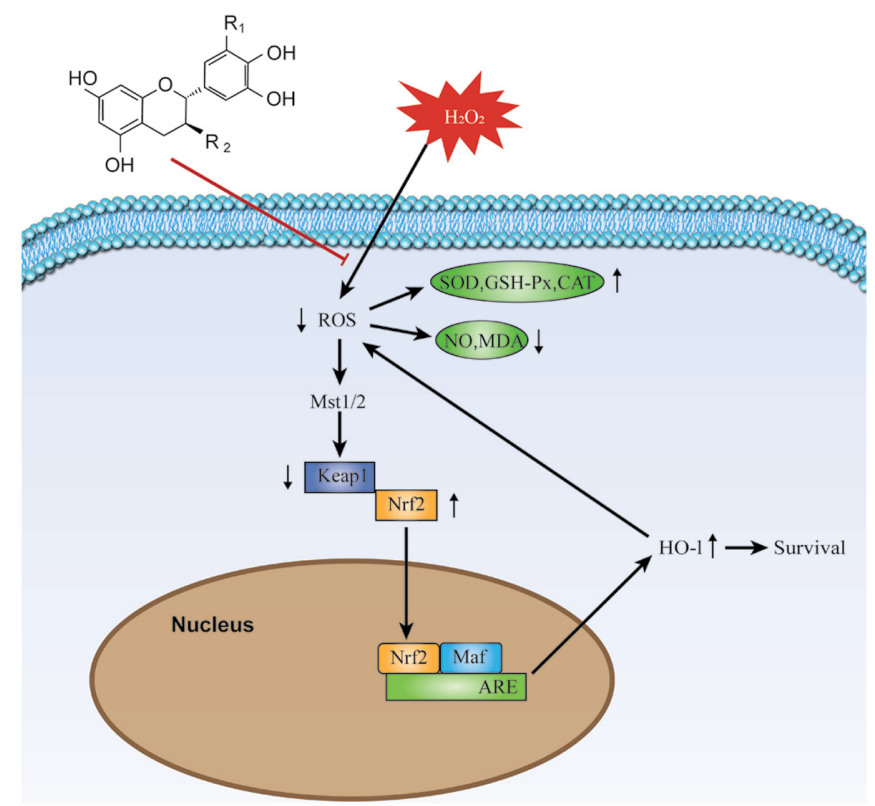

Figure 7. Molecular mechanism of TPs protection against $\mathrm{H}_{2} \mathrm{O}_{2}$-induced RAW264.7 cell injury. The excessive production of ROS in $\mathrm{H}_{2} \mathrm{O}_{2}$-injured RAW264.7 cells is alleviated and the balance of the oxidoreductase system is maintained by TPs. The expression of Nrf2 is directly affected by the change of intracellular ROS levels, following the Mst/Nrf2 axis maintenance of cellular redox balance and via Nrf2 binding to the ARE in the nucleus and thereby activating $\mathrm{HO}-1$ protein expression. Induction via the Mst/Nrf2 axis and the Keap1/Nrf2/HO-1 pathway appears to represent the antioxidant mechanism of TPs. TPs, tea polyphenols; ROS, reactive oxygen species; Nrf2, nuclear factor (erythroid-derived 2)-like 2; Mst, mammalian STE20-like protein kinase; HO-1, heme oxygenase 1; Keap1, Kelch-like ECH-associated protein 1; ARE, antioxidant response element; SOD, superoxide dismutase; GSH-Px, glutathione peroxidase; CAT, catalase; NO, nitric oxide; MDA, malondialdehyde; Maf, musculoaponeurotic fibrosarcoma; ARE, antioxidant response element.

$\sim 10-50 \mu \mathrm{M}$ EGCG) (41-43). Pharmacokinetics studies in humans or mice show that the peak serum concentrations of EGCG, EGC or ECG are affected by an individual's metabolism and the number of catechins in the ingested type of green tea ranged from $34.7 \mathrm{ng} / \mathrm{ml}-3.39 \mu \mathrm{g} / \mathrm{ml}$ (44-46). Accordingly, the concentrations of TPs and main substances used in the present study were comparable to their serum concentrations.

$\mathrm{H}_{2} \mathrm{O}_{2}$ can diffuse freely through the cell due to its membrane permeability (47). When an organism is stimulated by exogeneous $\mathrm{H}_{2} \mathrm{O}_{2}$, excessive ROS interferes with the balance of intricate defense mechanisms, triggering oxidative damage (48). Therefore, the $\mathrm{H}_{2} \mathrm{O}_{2}$-induced cell injury model is ideal for in vitro antioxidant research (15). Forman et al (49) reveal that $\mathrm{H}_{2} \mathrm{O}_{2}$ concentration in blood plasma is $\sim 1-5 \mu \mathrm{M}$, which would be $>100$-fold higher than that estimated to occur within cells. An estimated 100-fold concentration gradient from extracellular to intracellular is given for rough orientation and ensures to maintain homeostasis adjacent to normal cells (15). This also suggests that $400 \mu \mathrm{M} \mathrm{H}_{2} \mathrm{O}_{2}$ was a reasonable concentration in an injury cell model. Based on the results of flow cytometry analysis in the current study, all three doses of TPs alleviated the excessive production of ROS induced by $\mathrm{H}_{2} \mathrm{O}_{2}$.

The oxidoreductase system, which involves CAT, SOD, GSH-Px and MDA, serves an important regulatory role in $\mathrm{H}_{2} \mathrm{O}_{2}$-induced injury. A number of reports have revealed that natural antioxidants can increase CAT, SOD and GSH-Px levels and inhibit the production of MDA both in vivo and in vitro. Similarly, treatment with TPs or its four components can reduce MDA production and increase levels of antioxidant enzymes $(3,5,11)$. In the present study, $\mathrm{H}_{2} \mathrm{O}_{2}$-treated RAW264.7 cells that were exposed to TPs increased the levels of CAT, SOD and GSH-Px and decreased levels of MDA, as well as No. $\mathrm{H}_{2} \mathrm{O}_{2}$ can also increase NO levels in RAW264.7 cells, which in turn further promotes the production of $\mathrm{H}_{2} \mathrm{O}_{2}$, inhibiting catalase activity and creating a cycle of aggravated oxidative damage to cells $(25,50,51)$. The current data demonstrated that TPs efficiently reduced NO release, alleviating oxidative damage to RAW264.7 cells.

To elucidate the underlying protective mechanism of TPs in $\mathrm{H}_{2} \mathrm{O}_{2}$-injured RAW264.7 cells, the expression of the Mst/Nrf2 axis and Keap1/Nrf2/HO-1 pathway was evaluated. The Nrf2 transcription factor is an essential regulator of cellular responses against oxidative stress (52), which mainly activates the antioxidant response and promotes the production of antioxidant proteins and enzymes (53). In the cytoplasm of normal cells, Nrf2 is maintained at low levels by polymerizing into dimers and binding to Keap1, which facilitates polyubiquitination and enables proteasomal degradation of Nrf2 (54). When cells are exposed to excessive endogenous or exogenous ROS under conditions of stress, Nrf2 dissociates from Keap1, migrates to the nucleus and exerts its function (55), ultimately stimulating HO-1 activity (54). In addition, Nrf2 can mediate the expression of certain antioxidant factors including SOD, CAT and NAD(P)H quinone oxidoreductase 1 (54). In both animal and cell line models, the preventive and therapeutic effects of TPs are alleviated via the Nrf2/Keap1/HO-1 pathway $(56,57)$. In the present study, the results of RT-qPCR and western blotting revealed that TPs upregulated Nrf2 and HO-1 expressions, downregulated Keap1 expression and reversed oxidative damage in RAW264.7 cells induced by $\mathrm{H}_{2} \mathrm{O}_{2}$. The results suggested that the possible mechanisms in TPs-alleviated cellular damage may be through the modulation of Nrf2/Keap1/HO-1 pathway.

Recent research revealed that the Mst/Nrf2 axis maintains cellular redox homeostasis when sensing the production of ROS in macrophages (21). ROS recruits and activates the protective kinases Mst1 and Mst2, which induce Keap1 phosphorylation, prevent Keap1 polymerization and block Nrf2 ubiquitination and degradation. The stability of Nrf2 is a major factor for the protection of cells against oxidative damage (54). Consistent with previous studies, the results of the current study also supported the view that Mst1 and Mst 2 are markedly activated by $\mathrm{H}_{2} \mathrm{O}_{2}$-induced ROS release, achieving self-protection in RAW264.7 cells. In addition, the production of ROS was downregulated following TPs treatment, with Mst1 and Mst2 exhibiting lower expressions compared with the $\mathrm{H}_{2} \mathrm{O}_{2}$-treated group; however, the levels were still higher compared with the control group. The results suggested that the Mst/Nrf2 axis may be a specific regulatory system for the defense against oxidative damage induced by $\mathrm{H}_{2} \mathrm{O}_{2}$. However, the present study did not conduct verification experiments by intervention strategies, such as inhibitors, activators, some genes and epigenetic modifications, targeting the relative pathways. The promising findings are not conclusive due to some limitations of the present study. The underlying 
mechanism needs further investigation and will be addressed in future studies.

A number of epidemiological studies have been conducted to investigate the effects of tea consumption on human benefits with special reference to antioxidant, cancer and cardiovascular diseases. Tea drinking is shown to be associated with a lower risk for several types of cancer (58). During an 11-year follow-up, a prospective cohort study containing 285 males and 203 female cancer patients was conducted with green tea. Individuals who consumed $>10$ cups of green tea per day showed marked reductions of relative risk for lung, colon and liver cancers than other groups (<3 cups; 4-9 cups) (59). In addition, increasing frequency, duration and quantity of green tea consumed weakened the risk of prostate cancer (60). Therefore, a cell line model consuming TPs continuously will need to be established to simulate regular tea consumption in a follow-up study. In addition, two commonly used human cell lines, THP-1 and U937, will be used in future to identify the most effective dosage and frequency to achieve the maximum human health benefits.

In conclusion, TPs treatment was applied in the current study to induce antioxidant activity, reducing the effects of $\mathrm{H}_{2} \mathrm{O}_{2}$-induced cellular injury. The protective effects of TPs partly involved the reduction of intracellular ROS generation, NO release and MDA levels, along with the restoration of SOD and GSH-Px activity. The underlying mechanism may possibly be associated with the Mst/Nrf2 axis and Keap1/ Nrf2/HO-1 signaling pathway for the sensing and regulation of antioxidant defense (Fig. 7). Since the oxidative injury model serves a key role in screening antioxidants and protective substances, the current study provides further evidence for the application of TPs in pro-oxidant ROS-mediated oxidative stress.

\section{Acknowledgements}

The authors would like to thank Mrs. Jia-Qi Tan, Dr Yu-Jin Xu and Dr Ce-Shu Gao (Department of Neurology, Beijing Tsinghua Changgung Hospital, School of Clinical Medicine, Tsinghua University) for their technical support and assistance with data analysis.

\section{Funding}

The current study was supported by the National Natural Science Foundation of China (grant no. 81670090).

\section{Availability of data and materials}

The datasets used and/or analyzed during the current study are available from the corresponding author on reasonable request.

\section{Authors' contributions}

QL, YW and HX performed the experiments and analyzed the data; QL and ZQ obtained the data and wrote the manuscript. $\mathrm{XC}$ and $\mathrm{YZ}$ analyzed the data. JT, LL and CG conceptualized and guided the research. QL and HX confirmed the authenticity of all the raw data. All authors read and approved the final manuscript.

\section{Ethics approval and consent to participate}

Not applicable.

\section{Patient consent for publication}

Not applicable.

\section{Competing interests}

The authors declare that they have no competing interests.

\section{References}

1. Yang CS, Kim S, Yang GY, Lee MJ, Liao J, Chung JY and Ho CT: Inhibition of carcinogenesis by tea: Bioavailability of tea polyphenols and mechanisms of actions. Proc Soc Exp Biol Med 220: 213-217, 1999.

2. Khan $\mathrm{N}$ and Mukhtar $\mathrm{H}$ : Tea polyphenols in promotion of human health. Nutrients 11: 39, 2018

3. Zuo AR, Dong HH, Yu YY, Shu QL, Zheng LX, Yu XY and Cao SW: The antityrosinase and antioxidant activities of flavonoids dominated by the number and location of phenolic hydroxyl groups. Chin Med 13: 51, 2018.

4. Ganesan K and Xu B: A critical review on polyphenols and health benefits of black soybeans. Nutrients 9: 455, 2017.

5. Namal Senanayake SPJ: Green tea extract: Chemistry, antioxidant properties and food applications - A review. J Funct Foods 5: 1529-1541, 2013.

6. Gundimeda U, McNeill TH, Fan TK, Deng R, Rayudu D, Chen Z, Cadenas E and Gopalakrishna R: Green tea catechins potentiate the neuritogenic action of brain-derived neurotrophic factor: Role of 67-kDa laminin receptor and hydrogen peroxide. Biochem Biophys Res Commun 445: 218-224, 2014.

7. Ueda-Wakagi M, Nagayasu H, Yamashita Y and Ashida AH: Green tea ameliorates hyperglycemia by promoting the translocation of glucose transporter 4 in the skeletal muscle of diabetic rodents. Int J Mol Sci 20: 2436, 2019.

8. Griendling KK, Sorescu D, Lassègue B and Ushio-Fukai M: Modulation of protein kinase activity and gene expression by reactive oxygen species and their role in vascular physiology and pathophysiology. Arterioscler Thromb Vasc Biol 20: 2175-2183, 2000.

9. Moloney JN and Cotter TG: ROS signalling in the biology of cancer. Semin Cell Dev Biol 80: 50-64, 2018

10. He L, He T, Farrar S, Ji L, Liu T and Ma X: Antioxidants maintain cellular redox homeostasis by elimination of reactive oxygen species. Cell Physiol Biochem 44: 532-553, 2017.

11. Yan Z, Zhong Y, Duan Y, Chen Q and Li F: Antioxidant mechanism of tea polyphenols and its impact on health benefits. Anim Nutr 6: 115-123, 2020

12. Xing L, Zhang H, Qi R, Tsao R and Mine Y: Recent advances in the understanding of the health benefits and molecular mechanisms associated with green tea polyphenols. J Agric Food Chem 67: 1029-1043, 2019.

13. Wang D, Wang Y, Wan X, Yang CS and Zhang J: Green tea polyphenol (-)-epigallocatechin-3-gallate triggered hepatotoxicity in mice: Responses of major antioxidant enzymes and the Nrf2 rescue pathway. Toxicol Appl Pharmacol 283: 65-74, 2015.

14. Qi G, Mi Y, Fan R, Zhao B, Ren B and Liu X: Tea polyphenols ameliorates neural redox imbalance and mitochondrial dysfunction via mechanisms linking the key circadian regular Bmal1. Food Chem Toxicol 110: 189-199, 2017.

15. Sies H: Hydrogen peroxide as a central redox signaling molecule in physiological oxidative stress: Oxidative eustress. Redox Biol 11: 613-619, 2017.

16. Wen ZS, Liu LJ, OuYang XK, Qu YL, Chen Y and Ding GF: Protective effect of polysaccharides from Sargassum horneri against oxidative stress in RAW264.7 cells. Int J Biol Macromol 68: 98-106, 2014.

17. West AP, Brodsky IE, Rahner C, Woo DK, Erdjument-Bromage H, Tempst P, Walsh MC, Choi Y, Shadel GS and Ghosh S: TLR signalling augments macrophage bactericidal activity through mitochondrial ROS. Nature 472: 476-480, 2011.

18. Lambeth JD: NOX enzymes and the biology of reactive oxygen. Nat Rev Immunol 4: 181-189, 2004. 
19. Lin X, Bai D, Wei Z, Zhang Y, Huang Y, Deng H and Huang X: Curcumin attenuates oxidative stress in RAW264.7 cells by increasing the activity of antioxidant enzymes and activating the Nrf2-Keap1 pathway. PLoS One 14: e0216711, 2019.

20. Zhang XT, Sun XQ, Wu C, Chen JL, Yuan JJ, Pang QF and Wang ZP: Heme oxygnease-1 induction by methylene blue protects RAW264.7 cells from hydrogen peroxide-induced injury. Biochem Pharmacol 148: 265-277, 2018.

21. Wang P, Geng J, Gao J, Zhao H, Li J, Shi Y, Yang B, Xiao C, Linghu Y, Sun X, et al: Macrophage achieves self-protection against oxidative stress-induced ageing through the Mst-Nrf2 axis. Nat Commun 10: 755, 2019.

22. Yang CS, Lambert JD and Sang S: Antioxidative and anti-carcinogenic activities of tea polyphenols. Arch Toxicol 83: 11-21, 2009.

23. Green LC, Wagner DA, Glogowski J, Skipper PL, Wishnok JS and Tannenbaum SR: Analysis of nitrate, nitrite, and [15N] nitrate in biological fluids. Anal Biochem 126: 131-138, 1982.

24. Livak KJ and Schmittgen TD: Analysis of relative gene expression data using real-time quantitative PCR and the 2(- $\Delta \Delta \mathrm{C}(\mathrm{T}))$ Method. Methods 25: 402-408, 2001.

25. Wen ZS, Liu LJ, Qu YL, Ouyang XK, Yang LY and Xu ZR: Chitosan nanoparticles attenuate hydrogen peroxide-induced stress injury in mouse macrophage RAW264.7 cells. Mar Drugs 11: 3582-3600, 2013.

26. Rani V, Deep G, Singh RK, Palle K and Yadav UC: Oxidative stress and metabolic disorders: Pathogenesis and therapeutic strategies. Life Sci 148: 183-193, 2016.

27. Ahmed NA, Radwan NM, Aboul Ezz HS and Salama NA: The antioxidant effect of Green Tea Mega EGCG against electromagnetic radiation-induced oxidative stress in the hippocampus and striatum of rats. Electromagn Biol Med 36: 63-73, 2017.

28. Chen TS, Liou SY, Lin HH, Hung MY, Lin CC, Lin YM, Lin KH, Padma VV, Yao CH, Kuo WW, et al: Oral administration of green tea Epigallocatechin-3-gallate reduces oxidative stress and enhances restoration of cardiac function in diabetic rats receiving autologous transplantation of adipose-derived stem cells. Arch Physiol Biochem 127: 82-89, 2021.

29. Valu MV, Soare LC, Sutan NA, Ducu C, Moga S, Hritcu L, Boiangiu RS and Carradori S: Optimization of ultrasonic extraction to obtain erinacine A and polyphenols with antioxidant activity from the fungal biomass of hericium erinaceus Foods 9: 1889, 2020.

30. Urbańska B and Kowalska J: Comparison of the total polyphenol content and antioxidant activity of chocolate obtained from roasted and unroasted cocoa beans from different regions of the world. Antioxidants 8: 283, 2019.

31. Xia EQ, Deng GF, Guo YJ and Li HB: Biological activities of polyphenols from grapes. Int J Mol Sci 11: 622-646, 2010.

32. Xue HK, Tan JQ, Li Q, Cai X and Tang JT: Optimization ultrasound-assisted extraction of anthocyanins from cranberry using response surface methodology coupled with genetic algorithm and identification anthocyanins with HPLC-MS2. J Food Process Preserv 45: e15378, 2021.

33. Tan J, Li Q, Xue H and Tang J: Ultrasound-assisted enzymatic extraction of anthocyanins from grape skins: Optimization, identification, and antitumor activity. J Food Sci 85: 3731-3744, 2020

34. Xue H, Tan J, Li Q, Tang J and Cai X: Ultrasound-assisted deep eutectic solvent extraction of anthocyanins from blueberry wine residues: Optimization, identification, and HepG2 antitumor activity. Molecules 25: 5456, 2020.

35. Mukhtar H and Ahmad N: Cancer chemoprevention: Future holds in multiple agents. Toxicol Appl Pharmacol 158: 207-210, 1999.

36. Khan N and Mukhtar H: Tea polyphenols for health promotion. Life Sci 81: 519-533, 2007.

37. Frei B and Higdon JV: Antioxidant activity of tea polyphenols in vivo: Evidence from animal studies. J Nutr 133: S3275-S3284 2003.

38. Lagha $\mathrm{AB}$ and Grenier D: Tea polyphenols inhibit the activation of $N F-\kappa B$ and the secretion of cytokines and matrix metalloproteinases by macrophages stimulated with Fusobacterium nucleatum. Sci Rep 6: 34520, 2016.

39. Galati G, Lin A, Sultan AM and O'Brien PJ: Cellular and in vivo hepatotoxicity caused by green tea phenolic acids and catechins. Free Radic Biol Med 40: 570-580, 2006.

40. Isbrucker RA, Edwards JA, Wolz E, Davidovich A and Bausch J: Safety studies on epigallocatechin gallate (EGCG) preparations Part 2: Dermal, acute and short-term toxicity studies. Food Chem Toxicol 44: 636-650, 2006
41. Coyle CH, Philips BJ, Morrisroe SN, Chancellor MB and Yoshimura N: Antioxidant effects of green tea and its polyphenols on bladder cells. Life Sci 83: 12-18, 2008.

42. Yang GY, Liao J, Li C, Chung J, Yurkow EJ, Ho CT and Yang CS: Effect of black and green tea polyphenols on c-jun phosphorylation and $\mathrm{H}(2) \mathrm{O}(2)$ production in transformed and non-transformed human bronchial cell lines: Possible mechanisms of cell growth inhibition and apoptosis induction. Carcinogenesis 21: 2035-2039, 2000.

43. Ma YF, Zhao L, Coleman DN, Gao M and Loor JJ: Tea polyphenols protect bovine mammary epithelial cells from hydrogen peroxide-induced oxidative damage in vitro by activating NFE2L2/HMOX1 pathways. J Dairy Sci 102: 1658-1670, 2019.

44. Lee MJ, Maliakal P, Chen L, Meng X, Bondoc FY, Prabhu S, Lambert G, Mohr S and Yang CS: Pharmacokinetics of tea catechins after ingestion of green tea and (-)-epigallocatechin-3-gallate by humans: Formation of different metabolites and individual variability. Cancer Epidemiol Biomarkers Prey 11: 1025-1032, 2002.

45. Nakagawa K, Okuda S and Miyazawa T: Dose-dependent incorporation of tea catechins, (-)-epigallocatechin-3-gallate and (-)-epigallocatechin, into human plasma. Biosci Biotechnol Biochem 61: 1981-1985, 1997.

46. Ullmann U, Haller J, Decourt JP, Girault N, Girault J, Richard-Caudron AS, Pineau B and Weber P: A single ascending dose study of epigallocatechin gallate in healthy volunteers. J Int Med Res 31: 88-101, 2003.

47. Avshalumov MV, Bao L, Patel JC and Rice ME: $\mathrm{H}_{2} \mathrm{O}_{2}$ signaling in the nigrostriatal dopamine pathway via ATP-sensitive potassium channels: Issues and answers. Antioxid Redox Signal 9: 219-231, 2007.

48. Mao X, Gu C, Chen D, Yu B and He J: Oxidative stress-induced diseases and tea polyphenols. Oncotarget 8: 81649-81661, 2017.

49. Forman HJ, Bernardo A and Davies KJ: What is the concentration of hydrogen peroxide in blood and plasma? Arch Biochem Biophys 603: 48-53, 2016.

50. Brown GC: Reversible binding and inhibition of catalase by nitric oxide. Eur J Biochem 232: 188-191, 1995.

51. McBride AG, Borutaité V and Brown GC: Superoxide dismutase and hydrogen peroxide cause rapid nitric oxide breakdown, peroxynitrite production and subsequent cell death. Biochim Biophys Acta 1454: 275-288, 1999.

52. Jadeja RN, Upadhyay KK, Devkar RV and Khurana S: Naturally occurring Nrf2 activators: Potential in treatment of liver injury. Oxid Med Cell Longev 2016: 3453926, 2016.

53. Ma Q: Role of nrf2 in oxidative stress and toxicity. Annu Rev Pharmacol Toxicol 53: 401-426, 2013.

54. Nguyen T, Nioi P and Pickett CB: The Nrf2-antioxidant response element signaling pathway and its activation by oxidative stress. J Biol Chem 284: 13291-13295, 2009.

55. Shukla K, Pal PB, Sonowal H, Srivastava SK and Ramana KV: Aldose reductase inhibitor protects against hyperglycemic stress by activating Nrf2-dependent antioxidant proteins. J Diabetes Res 2017: 6785852, 2017.

56. Qi GY, Mi YS, Fan R, Li RN, Wang YW, Li XY, Huang SX and Liu XB: Tea polyphenols ameliorate hydrogen peroxide- and constant darkness-triggered oxidative stress via modulating the Keap1/Nrf2 transcriptional signaling pathway in HepG2 cells and mice liver. RSC Advances 7: 32198-32208, 2017.

57. Wang D, Zhang M, Wang T, Liu T, Guo Y and Granato D: Green tea polyphenols mitigate the plant lectins-induced liver inflammation and immunological reaction in C57BL/6 mice via NLRP3 and Nrf2 signaling pathways. Food Chem Toxicol 144: 111576,2020

58. Sueoka N, Suganuma M, Sueoka E, Okabe S, Matsuyama S, Imai K, Nakachi $\mathrm{K}$ and Fujiki $\mathrm{H}$ : A new function of green tea: Prevention of lifestyle-related diseases. Ann N Y Acad Sci 928: 274-280, 2001.

59. Jian L, Xie LP, Lee AH and Binns CW: Protective effect of green tea against prostate cancer: A case-control study in southeast China. Int J Cancer 108: 130-135, 2004.

60. Miyata Y, Shida Y, Hakariya T and Sakai H: Anti-cancer effects of green tea polyphenols against prostate cancer. Molecules 24: 193, 2019.

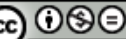

This work is licensed under a Creative Commons Attribution-NonCommercial-NoDerivatives 4.0 International (CC BY-NC-ND 4.0) License. 